\title{
TWO REFERENCES TO A LEVI DOCUMENT IN AN EPISTLE OF AMMONAS
}

\author{
by \\ JOHANNES TROMP \\ Leiden
}

In the Greek version of the seventh epistle of the Egyptian monk Ammonas two quotations occur, apparently from an apocryphal text attributed to, or narrating about Jacob's son Levi.' The quotations cannot be retrieved in any Jewish or early Christian source, including the numerous fragments of the Aramaic Levi Document. It is the aim of this note to investigate from what kind of Levi document Ammonas' quotations may have been taken.

\section{The Epistles of Ammonas}

There have been many Egyptian Christians bearing the name Ammonas or Ammonius. ${ }^{2}$ However, there is unanimity in the ascription of the letters under discussion to one Ammonas in particular, namely the pupil of abba Antony the Great ( +356$)$, and his successor as the leader of a group of anachoretic monks in Pispir on the Nile. This attribution rests on the fact that the author tells his readers what Antony has said to "us" (Syr. IX 3). The assumption that Ammonas was Antony's pupil and successor then explains many other biographical allusions in the letters, which are in agreement with the details in various other sources mentioning Ammonas. ${ }^{3}$

${ }^{1}$ Dr. S.P. Brock drew the attention of Father A.-M. Denis to this passage, who alerted Prof. M. de Jonge to it. I wish to thank the latter for his critical reading of an earlier draft of this note.

${ }^{2}$ For a catalogue, see, e.g., the numerous articles on Ammon, Ammonas, Ammone and Ammonius in the Dictionnaire d'histoire et de géographie ecclesiastiques II (Paris: Letouzey, 1914), cols. 1308-1318; cf. F. Nau, "Ammonas, successeur de Saint Antoine," Patrologia orientalis XI (Paris: Firmin-Didot/Freiburg im Breisgau: Herder, 1916) 393. In the Greek

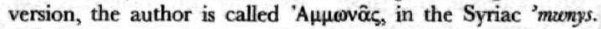

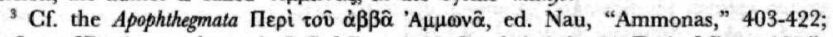
Rufinus, Historia monachorum, in J.-P. Migne (ed.), Patrologia latina 21 (Paris: Migne, 1878), cols. 387-462; col. 432 ("De Pithyrione"). 
Athanasius became acquainted with this Ammonas during his stay in the Egyptian desert (356-361). Around 380, Ammonas knew a certain Poemen (fl. ca. 400), and when the Historia monachorum was written (around 400), Ammonas had died. This enables us to date the letters of our Ammonas to the second half of the fourth century. ${ }^{4}$

There are three editions of the epistles of Ammonas.

(1) In 1641 the Maronite professor of theology and oriental languages, Abraham Ecchellensis, published a Latin translation of an Arabic manuscript, Twenty Epistles of our Holiest Father, the Blessed Antony the Great, the Parent of all Monks. The first seven of these epistles had already been translated into Latin from a Greek codex (now lost) and published by Symphorien Champier in 1515, also under the name of Antony. Both translations are included in Migne's collection of works by, and ascribed to, Antony the Great. ${ }^{5}$ One reference to Levi is found in the nineteenth of this collection (Ar. XIX). Since Ecchellensis' book is not available to me, I shall use Migne's reprint of it.

(2) For his edition of a Syriac version, M. Kmosko could use ten manuscripts (mainly from the British Museum; the oldest is dated 534) containing fourteen epistles by Ammonius the Hermit, which appeared to be largely identical to the twenty epistles attributed to Antony. The authorship of Antony had been doubted already, ${ }^{6}$ so that the ascription to Ammonas, a pupil of Antony, was established. ${ }^{7}$ Parts of the nineteenth epistle in Ecchellensis' collection correspond to the thirteenth epistle in this Syriac collection. ${ }^{8}$

(3) Immediately following Kmosko's edition of 1915, F. Nau published seven Greek epistles by Ammonas, based on a rather obscure publication by one Augustine, a monk in St. John's monastery on the Jordan, containing five epistles, and on four additional manuscripts each containing one or two epistles. ${ }^{9}$ The seventh of this collection (Gr. VII) corresponds to Ar. XIX and Syr. XIII.

\footnotetext{
4 Nau, "Ammonas," 393-395; on Ammonas, see further B. Altaner and A. Stuiber, Patrologie (Freiburg/Basel/Vienna: Herder, ${ }^{8} 1978$ ) 262 and 600.

${ }^{5}$ Ammonas, Epistulae (sub nomine S. Antonii), ed. S. Champier (1515), reprinted in J.-P. Migne (ed.), Patrologia graeca 40 (Paris: Migne, 1863), cols. 999-1066. On the history of this edition, see M. Kmosko, "Ammonii eremitae epistolae," Patrologia orientalis X (Paris: Firmin-Didot/Freiburg im Breisgau: Herder, 1915) 561-562. O. Bardenhewer, Geschichte der althirchlichen Literatur III (Freiburg im Breisgau: Herder, 1912), p. 81, gives the year 1516 for Champier's edition.

${ }^{6}$ Bardenhewer, Geschichte III, 81.

'It was already known, from a Medieval catalogue, that a certain Ammonius had written epistles; see Kmosko, "Ammonii epistolae," 555.

${ }^{8}$ Kmosko, "Ammonii epistolae," 561-563.

${ }^{9} \mathrm{Nau}$, "Ammonas," 397.
} 
A fourth, Georgian version has been reported to exist; the letter under discussion is the eleventh in the Georgian collection, but it has not yet been published. ${ }^{10}$

\section{The Syriac Epistle XIII and its Greek and Arabic Counterparts}

In order to establish the context in which Ammonas refers to words of Levi, I summarize the contents of the epistle under discussion, starting from Syr. XIII as the version that retains the most primitive text form (see below).

In the first section Ammonas introduces the subject: he greets his readers in a humble spirit, which is the spirit of peace that gives a sweet scent to the righteous souls, because it is free of passions, and pure.

In the second section the author sets out to explain the relationship between purification, and the bestowal of the holy spirit. This spirit of truth, the Paraclete (John 16:7,13), should be distinguished from the spirit of repentance. The former is given to the perfect souls only. Only when the spirit of repentance has called a number of souls and purified them completely, it brings them to the holy spirit, which then continuously fills them with fragrant scents and sweetness, as it is written: "Who knows the delight of the spirit, but those in whom it has dwelled?" Very few people have proved worthy of this, even of the spirit of repentance.

The third section compares the possession of the spirit to that of a pearl: a pearl is not found in just any house, but only in royal palaces; likewise the spirit is only found in the souls of the perfectly righteous, so that those who have earned it thank God greatly, saying: "We praise you, God, for you have given us that spirit which you have given to your servants who please you." This is the pearl the Gospel intends when it says that it is bought by the man who sold all his goods to obtain it (Matt. 13:45-46), and this is the treasure which was hidden in the field until it was found by the man, who was filled with joy (Matt. 13:44). To those in whom the spirit dwells, it reveals the greatest mysteries, and to them day and night are the same, and they are filled with the spirit as long as they are in the flesh (in "this tent").

${ }^{10}$ G. Garitte, Catalogue des manuscrits géongiens litteraires du Mont Sinaï (CSCO 165; Subsidia 9; Louvain: Peeters, 1956) 103-108. Garitte published Georg. I (= Gr. II = Syr. II $)$ in "De unius ex Ammonae epistulis versione iberica," Le Muséon 89 (1976) 123-131, mainly to exemplify his thesis that the Syriac is more likely to have been the source of the Georgian version than the Greek (p. 124). 
Ammonas adds in section 4 that God has always been with him and has made him prosper even more since he has lived in solitude. He would like to have his pupils with him, because of the many revelations he receives, new ones every day. He then continues to speak in sections 5-7 about temptation (a favorite topic of Ammonas), which nobody can overcome without the help of the spirit of God. The temptations of Christ, in the desert and at the occasion of his descent into hell, as well as the temptation of Joseph's emprisonment serve to illustrate this point. ${ }^{11}$

Section 8 is presented as a post-scriptum: "After I had written the letter, I remembered the words written in Ezekiel,"'12 which contain an appropriate exemplum from the throne-vision (Ezek. 1). There an animal with four faces is described, namely the face of a Cherub (a face characteristic of anyone in whose soul the spirit dwells), that of a human (which the spirit assumes when it sets out to find a man), that of a bull (which stands for the strength to fight Satan in temptation), and that of an eagle (which flies high in the sky and thus represents the proximity to God of a soul possessed by the holy spirit). If the recipients of Ammonas' letter wish to know more about this animal, they should ask, and he will come and tell them more.

In the concluding admonitions, Ammonas wishes everybody strength in their struggle with the devil's temptations (section 10), whereas the final section suddenly appears to be addressed to one particular, but anonymous "father and teacher," to whom a rich harvest is promised, as to all good workers in the fields of God. ${ }^{13}$

The Greek version of this epistle is much shorter. The first three sections run more or less parallel to those in the Syriac version, but the fourth section (in which Ammonas claims to receive new revelations every day) is absent in the Greek. The fifth and the first half of the sixth section are present in the Greek, but the second half of the sixth section (on Christ's descent into hell), and the seventh (on Joseph's temptation) are absent in the Greek. Also, the Greek version has a different ending, admonishing the readers to praise God in all circumstances because he has led us up from darkness and restored us to our

\footnotetext{
"It may be noted that this temptation of Joseph is mentioned only briefly; there is no connection with this theme in, e.g., the Testaments of the Twelve Patriarchs.

${ }^{12}$ A similar formula ties Syr. X to Syr. IX.

${ }^{13}$ Possibly, this person was Pithyrion, the successor of Ammonas as the leader of the anachoretic community which Ammonas had been compelled to leave; so F. Klejna, "Antonius und Ammonas. Eine Untersuchung über Herkunft und Eigenart der ältesten Mönchsbriefe," Zeitschrift für katholische Theologie 62 (1938) 309-348: pp. 322-326.
} 
former height. There is no post-scriptum, no treatment of Ezekiel's throne-vision, no explanation about the hard work that living in the spirit entails, and no encouragement for the good teacher. What is present, then, is the argument that the holy spirit of truth is given only to the perfectly righteous, that it is therefore as rare as a treasure, that it reveals great mysteries, and that it rescues from temptation.

In his discussion of the relationship between Syr. IX-X and Gr. IV, F. Klejna concluded that the Greek version is a secondary compilation, in which the redactor strives to omit all purely personal matters and all repetition. This conclusion seems valid for Syr. XIII and Gr. VII as well. ${ }^{14}$ On the other hand, Klejna has also shown that the Greek version, notwithstanding its fragmentary state, is textually more reliable. ${ }^{15}$

The Arabic version (Ar. XIX) is more elaborate than Syr. XIII, but corresponds to it in structure. Only in the middle, there is a large interpolation. To the conclusion the equivalent of Syr. XIV is added, separate in the Syriac collection, but integrated into Ar. XIX. The Arabic version is available only in a 17 th-century Latin translation. I am unable to make a judgment upon the character and quality of the Latin translation. The textual value of the Arabic version is therefore uncertain.

\section{Two Quotations from a Levi Document}

In Gr. VII 2, 3 two references are made to words of Levi. The content of these quotations was given already in the summary of the Syriac above.

(1) The first quotation is given in connection with Ammonas' argument that the holy spirit is given to a few only, but is unlimited in

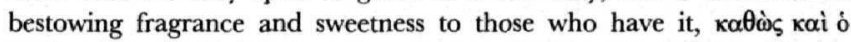

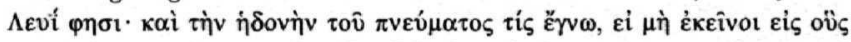

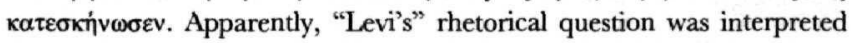
by Ammonas to mean: "Nobody knows how very delightful the spirit is, except the few in whom it dwells."

This quotation is present in Syr. XIII 2 and Ar. XIX (Migne 1051B) as well, but not ascribed to Levi; it is introduced by the simple formula ' $y k n$ ' d'myr or sicuti dicitur. This formula may suggest a scriptural quotation, but can also be understood as a general formula, which camouflages the obscurity of the quotation. It is in any case unlikely

\footnotetext{
${ }^{14}$ Klejna, "Antonius und Ammonas," 318. In footnote 10, Klejna summarily remarks that Gr. VII is evidently an excerpt of Syr. XIII.

is Klejna, "Antonius und Ammonas," 319.
} 
that the general formula would have been replaced by an explicit reference to some apocryphal source containing words of Levi. ${ }^{16}$ It may therefore be assumed that the ascription to Levi is by Ammonas.

(2) The second quotation appears in the same context as the first one. It intends to illustrate the exceptionality of the bestowal of the holy spirit. Like a precious pearl, it is found only in the souls of the

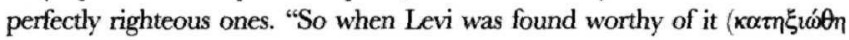

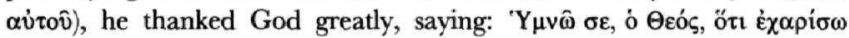

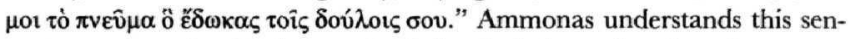
tence to mean that Levi recognized that he belonged to the select group of the servants of God, to whom the spirit is presented.

In Syr. XIII 3 this sentence is phrased in a more general way. In this instance, it is not even recognizable as a quotation. In this version we read that the spirit is found only in the souls of the perfectly righteous ones "like those, who had earned it, and greatly honoured God, speaking thus: We praise you, God, for you have given us that spirit, that you have given to all the servants who please you." Because the ascription of this particular praise to Levi is absent, this sentence in the Syriac loses much of its exemplary force. The apparent weakness of this sentence argues against its originality.

Moreover, the attribution to Levi is present in Ar. XIX (Migne 1051C), which seems to conflate both readings: Cum autem habitaverit in istis hic Spiritus, maximas agent Deo gratias multamque laudem; quoniam meruerunt Spinitum sanctum in illis habitari, sicut meruit illum Levi, et egit Domino maximas gratias, dicens: Benedicam te, Domine, qui edocuisti me Spiritu quem dedisti servis tuis. ${ }^{17}$

It may therefore be safely assumed that the two sayings attributed to Levi in Gr. VII are indeed quotations from a writing in which Levi is presented as praising God for having bestowed the holy spirit upon him.

\section{The Meaning of the Quotations}

In this section I shall look more closely into the form, meaning, and possible provenance of the quotations. A preliminary remark concerning the way in which Ammonas generally treats his sources is in order.

\footnotetext{
${ }^{16}$ It should be noted that the Syriac editor apparently had no fundamental objections against apocryphal quotations, which are relatively numerous in his collection.

${ }^{17}$ The quotation is followed in Ar. XIX, not by a continuation of the quotation, but by a secondary, explanatory paraphrase: Dixit etiam: Benedictus es, Domine, qui dedisti sanctis tuis honorem amnibus divituis praestantiorem: equidem non valeo Spinitus divitianum magnitudinem aspicere, quem elargitus es sanctis tuis (Migne 1051C-D).
} 
A comparison of Ammonas' quotations with the identifiable sources in the Septuagint and the New Testament reveals that Ammonas generally quotes the Old Testament (especially the Psalms), and also known apocrypha, such as the Ascension of Isaiah, quite accurately, but is much freer in his references to the New Testament. ${ }^{18}$ This phenomenon may perhaps be explained by assuming that both Ammonas and his readers were far more familiar with the New Testament writings than with the Old Testament. If all parties involved are well acquainted with the instance to which the author refers, it is not necessary to transcribe such a passage exactly. The same phenomenon occurs when Ammonas refers to the narratives from Genesis. He hardly quotes them, but simply calls the stories to mind. However, when the abba wishes to impart to his readers a particularly profound saying he found when reading and ruminating his Psalterion, ${ }^{19}$ his tendency to quote literally is natural. If this view of how Ammonas treated biblical quotations is correct, it can be assumed that the quotations of words ascribed to Levi, if they indeed come from some written source, are literal.

I shall now discuss the quotations themselves. Only then shall I consider the possibility that they are not quotations at all, but fake or bluff.

If we isolate the quotations from their context in Ammonas, the genre of the source from which they derive is quite clear, especially if presented in reverse order: ${ }^{20}$

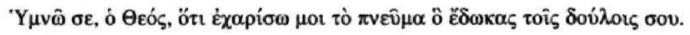

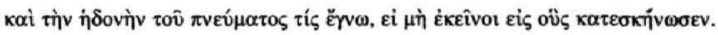

No doubt, these are lines from a thanksgiving prayer, comparable to, e.g., the Hodayoth known from the Qumran-scrolls, so labeled after the

18 The following New Testament quotations are conflated, or otherwise mangled in the Greek epistles: III 1 (Eph. 3:14-19); IV 2 (Jas. 5:13); V 3 (Prov. 14:12); V 5 (Luke 24:49); VII 2 (John 16:7,13); VII 7 (an allusion to Col. 1:13; Nau less felicitously compares Eph. 6:12). Apparently, Ammonas knew Heb. 5:14 (quoted accurately both in IV 1 and $\mathrm{V}$ 4) by heart.

${ }^{19}$ For the constant meditation on Scripture among the Egyptian monks, especially on the Psalter (which circulated in handy, separate editions), see D. Burton-Christie, The Word in the Desert. Scripture and the Quest for Holiness in Early Christian Monasticism (Oxford: UP, 1993), chapter 4, "The Use of Scripture in the Desert," 107-133.

${ }^{20}$ From Gr. VII 3 it appears that Ammonas, for the sake of his argument, may well reverse the order of the text to which he is referring. In order to characterize the spirit as a priceless possession, he first refers to Matt. 13:45-46 (about the man who sold all his goods to buy a pearl), and then to the preceding verse, Matt. 13:44 (about the treasure hidden in a field). Somewhat earlier in the same section, Ammonas without effort conflates John 16:7 and 13. Although Ammonas deals more easily with New Testament texts than with other texts, it is clear that he does not let his sources dictate his own argument. 
stereotyped introduction אודכה אדוני, "I praise you, Lord." Of course, whether these lines in their original context immediately followed each other, cannot be ascertained, but the possibility that the former is the incipit of the prayer cannot be ruled out.

What is said in these lines, is of a very traditional nature. Many Hodayoth, especially in the final columns of $1 \mathrm{QH}$, not only have the formulaic address "I praise you, Lord," but also include a grateful recognition of the receipt of God's holy spirit. See, for instance, 1QH VII 6-7: "I praise you, Lord, for you have sustained me through your strength, and you have poured your holy spirit on me"; cf. XVII 26: "[I praise you, Lord, for] you have showered [your] holy spirit over your servant."

The second line is at home in the wisdom tradition. In many instances,

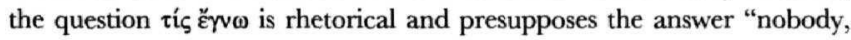
at least no mortal being." The object of the phrase is some kind of knowledge unattainable for the human mind, unless it is revealed by God. ${ }^{21}$ See, for instance, Sir. 1:6,8: "To whom the root of wisdom has

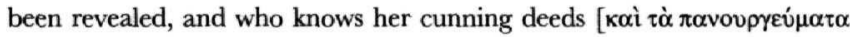
tí ह̌ $\gamma v \omega]$ ? One only is wise, very formidable, who is seated on his throne." Correlated with ei $\mu$ í, Sap. Sal. 9:17 provides a close paral-

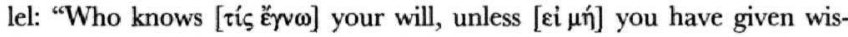

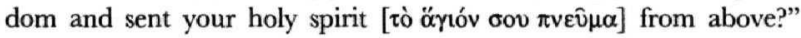

These parallels also reflect the traditionally close association of wisdom and God's spirit, an association so well-known that it does not require further substantiation here..$^{22}$

The sweetness of wisdom is a recurring motif in Ammonas' epistles, ${ }^{23}$ but also in Jewish sources from the Hellenistic and Roman periods. In Sir. 24:20 wisdom is called sweeter than honey; see also Philo Quod det. 117; Gig. 26. In Fuga 138-139 Philo offers an allegorical interpretation of the manna descending from heaven, "sweeter than honey and whiter than snow": it is a divine ordinance (Exod. 16:16) that fills the

${ }^{21}$ M.E. Stone, "Lists of Revealed Things in the Apocalyptic Literature," in: W. Lemke, D. Miller, F.M. Cross (eds.), Magnalia Dei = The Mighty Acts of Gad. Essays on the Bible and Archaeology in Memory of G. Emest Wright (Garden City, N.Y.: Doubleday, 1976) 414452; repr. in M.E. Stone, Selected Studies in Pseudepigrapha and Apocrypha, with Special Reference to the Armenian Tradition (SVTP 9; Leiden: Brill, 1991) 379-414.

${ }^{22}$ Wisdom is identified with God's spirit in the Wisdom of Solomon (e.g., 1:6; 7:22). For the close relationship between God's $\pi v \varepsilon \hat{\mu} \mu \alpha$ and wisdom in various other traditions, see H,J. de Jonge, "Sonship, Wisdom, Infancy: Luke ii. 41-5la," New Testament Studies 24 (1977-1978) 317-354; esp. pp. 348-349, referring, inter alia, to T. Lai $2: 3$ in ms. $e$.

${ }^{23}$ See Gr. II 1 and Gr. III 1; on both occasions, Ammonas quotes Ps. 18:11. 
visionary soul with light and sweetness. No doubt, the interpretation of manna as the sweet heavenly nourishment of wisdom (cf. Philo, Heres 119) also underlies the allegory of the honeycomb in Joseph and Aseneth 16. After Aseneth has converted to Judaism, this story relates, a heavenly messenger gives her honey to eat; then a multitude of bees ("white as snow") cover her, and the largest bees position themselves on her lips, symbolizing that henceforth words of wisdom ("sweet as honey") will flow from her mouth. ${ }^{24}$

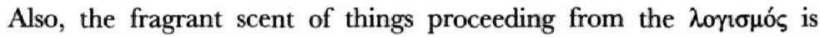

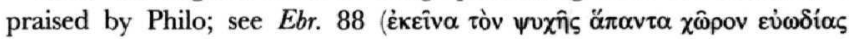

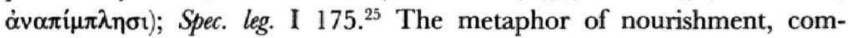
bined with a pleasant smell, for wisdom is also found in 1 En. 32:3-4

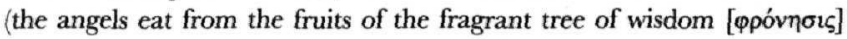
in Paradise).

In Jewish and Christian texts i் $\delta$ oví is rarely assessed favourably. ${ }^{26}$ It is often associated with (excessive) eating and drinking, and hence with moral corruption (e.g., Ep. Arist. 108; 277; T. Judah 13:6; T. Ben.

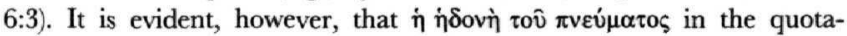
tion from "Levi" is meant positively, ${ }^{27}$ and should be understood in terms similar to the metaphors of sweetness and fragrance.

It appears that the quotations under discussion are of a traditional, rather general nature. Combined with the fact that no equivalent can be found in the known literature connected with Levi, one might be tempted to surmise that Ammonas' so-called quotations do not refer to existing writings at all, but are simply mystifications (not unlike the references to the writings of Enoch in, e.g., the Testaments of the Twelve

${ }^{24}$ C. Burchard, Untersuchungen zu Jaseph und Aseneth (Tübingen: Mohr, 1965); this interpretation was withdrawn by Burchard in "The Importance of Joseph and Aseneth for the Study of the New Testament: A General Survey and a Fresh Look at the Lord's Supper," NTS 33 (1987) 102-134; esp. pp. 113-116; repr. in id., Gesammette Studien zu Joseph und Aseneth (SVTP 13; Leiden: Brill, 1996) 263-295; esp. pp. 274-277; it was rightly reasserted by, e.g., R.D. Chesnutt, From Death to Life. Conversion in Joseph and Aseneth (JSP Supp. 16; Sheffield: JSOT Press, 1995) 131. For honey and bees as metaphors for divine inspiration and wisdom revealed by God or the gods, see also J.H. Waszink, Biene und Honig als Symbol des Dichters und der Dichtung in der griechisch-römischen Antike (RheinischWestfalische Akademie der Wissenschaften; Vorträge G 196; Opladen: Westdeutscher Verlag, 1974).

${ }^{25}$ Both instances are taken from allegories of incense sacrifices.

${ }^{26}$ It may be noted that in the only instance in which the Septuagint uses jiovn in an unequivocally positive meaning ("taste," namely "pleasant taste"; Num. 11:8), it also refers to the taste of manna.

${ }^{27}$ Neutral or (conditionally) positive appraisals of $\eta \delta \delta$ nv do occur in the patristic literature; see G.W.H. Lampe, A Patristic Greek Lexicon (Oxford: Clarendon, 1961) 60lb$602 \mathrm{~b}$, esp. sections 3 and 12 . 
Patriarchs).$^{28}$ However, even in this case, the choice of Levi as Ammonas' authority may not be accidental.

Levi may have been invoked as the typical ancient authority to support Ammonas' assertions. The hermit claims abundant knowledge of divine mysteries, receiving fresh revelations day in day out, and one might be tempted to think that some heavenly, or secret book of Levi is suggested to have been included. ${ }^{29}$ However, this possibility should be dismissed forthwith. Although Ammonas often quotes clauses and sentences which are irretrievable in the literature known to us, his quotations do not suggest that the author has had access to arcane writings, but on the contrary all suggest sources that the reader might more or less easily retrieve.

A related possibility, namely that the reverend father bluffed his way through the sacred literature, not expecting his hermit pupils to check his references ${ }^{30}$ can be discarded as well, precisely because the quotations under discussion are of such a general nature. Especially the second quotation, "I praise you, Lord, because you have given me your spirit \&c.," is most likely a reference to some existing text, because the quotation is in itself insignificant, but well conceivable as a reference to a prayer containing something comparable to the subject matter Ammonas is presently addressing. Such a prayer may have belonged to the literature he had ready at hand when composing this epistle, and may have been interpreted by Ammonas as asserting that the spirit is given to a few only, the perfectly righteous servants of God.

\section{The Source of the Quotations}

What may have been the source of Ammonas' quotations?

In a number of Jewish and early Christian sources of the centuries before and after the beginning of the common era, Levi is presented

${ }^{28}$ Cf. H.W. Hollander and M. de Jonge, The Testaments of the Twelve Patriarchs. A Commentary (SVTP 8; Leiden: Brill, 1985) 39-40.

${ }^{29}$ The tradition that Levi (and his successors) had access to heavenly wisdom is wellestablished in the Aramaic Levi Document, Jubilees, Joseph and Aseneth, and the Testaments of the Tuelve Patriarchs, cf. 4Q Qahat and 4Q Amram, as well as the Assumption of Moses. See M. de Jonge and Joh. Tromp, "Jacob's Son Levi in the Pseudepigrapha of the Old Testament and Related Literature," in: T.A. Bergren and M.E. Stone (eds.), Biblical Figures Outside the Bible (Minneapolis: Fortress, 1997) (forthcoming).

${ }_{30}$ This possibility is suggested by such introductory formulas as "as John has said somewhere" (Syr. XIII 10; absent in Gr. VII); the passage thus introduced does not occur in the known texts of the Gospel; but see the remarks above about the almost casual dealing with the New Testament, which is quoted by heart, and then of course may attract, so to speak, apocryphal sayings. 
as an inspired prophet (possessing, therefore, the spirit of God), and as an immaculate saint (in accordance with Ammonas' argument that the spirit is bestowed on the perfectly righteous only). ${ }^{31}$ In none of these sources (namely, Fubilees 30-32, the Aramaic Levi Document, and the Testament of Levi) do the lines quoted occur, although the prayer from which they probably derive would not have been out of place in them. Indeed, fub. 32:1 mentions that Levi, after having received a vision in which he was called to the priesthood, "woke up from his sleep and blessed the Lord." In T. Levi 5:7, a similar situation is depicted.

However, it is the so-called Aramaic Levi Document (ALD) which will actually have contained a prayer of Levi. Some fragments of such a prayer were found among the Dead Sea Scrolls (4Q Levi ${ }^{b}$ aram) $;^{32}$ the contents of this prayer can be fruitfully compared to an addition to T. Levi 2:3 in manuscript $e$ (Koutloumous 39), which probably derives from a Greek version of the Aramaic Levi Document. This Levi Document must have served as a major source for the author of the Testaments of the Twelve Patriarchs. This author (active around 200 C.E.) has abbreviated and heavily redacted the material he found in the Levi Document; the eleventh-century scribe responsible for ms. $e$ secondarily reinstated some passages from the Levi Document (which therefore must still have been extant in his days). ${ }^{33}$

The lines quoted by Ammonas do not derive from this Levi Document either, at least not from the document in the form known at present. A few remarks, however, are in order.

(1) In lines 5-8, the opening lines of the prayer of Levi in ms. $e^{34}$ a subject matter is introduced that resembles both the quotations in

${ }^{31}$ M. de Jonge and Joh. Tromp, "Jacob's Son Levi."

${ }^{32}$ See M.E. Stone and J.C. Greenfield, "The Second Manuscript of Aramaic Levi Document from Qumran (4Q Levi' aram)," Le Musion 109 (1996) 1-15.

${ }^{33}$ M. de Jonge, "The Testament of Levi and 'Aramaic Levi'," Reoue de Qumran 13 (1988) 367-385; repr. in: H.J. de Jonge (ed.), Jewish Eschatology, Early Christian Christology and the Testaments of the Twelve Patriarchs. Collected Essays of Marimus de Jonge (SuppNovT 63; Leiden: Brill, 1991) 244-262; see also his forthcoming "Levi in 'Aramaic Levi' and in the Testament of Levi," to be published in the proceedings of the second international symposium of the Jerusalem Orion Center for the Study of the Dead Sea Scrolls and Associated Literature on Pseudepigraphic Perspectives: The Apocmpha and the Pseudepigrapha in Light of the Dead Sea Scrolls, held in January 1997.

${ }^{34}$ The line numbers used were introduced by J.T. Milik, "Le Testament de Lévi en araméen. Fragment de la grotte 4 de Qumrân," Revue Biblique 62 (1955) 398-406, and adopted in M. de Jonge et alii (eds.), The Testaments of the Twelve Patriarchs. A Critical Edition of the Greek Text (PVTG I, 2; Leiden: Brill, 1978) 25; as well as in the translated reconstructions of the Aramaic Levi Document by J.C. Greenfield and M.E. Stone: H.W. Hollander and M. de Jonge, The Testaments of the Twelve Patriarchs. A Commentay (SVTP 8; Leiden: Brill, 1985) 458-460; and in idem, "The Second Manuscript," 7-9. 
Ammonas' epistle, and the other contents of the epistle. In line 8 Levi is said to ask God for his spirit and wisdom; these concepts stand in contrast to the unrighteous spirit and evil thoughts, mentioned in line 7 (cf, 4Q Levi ${ }^{\text {b }}$ aram, fragment 1, lines 12-15). (2) In line 11 (not extant in $4 Q$ Levi), Levi asks that God grants him to be a good servant of his; in line 17 (also not extant in 4Q Levi) Levi calls himself a servant of God. (3) Purity plays an important role in this prayer of Levi. Before praying, Levi is said to perform cleansing rituals (lines I-2; hardly extant in $4 Q$ Levi), which are directly associated with righteous behaviour (line 2); in line 14 (not extant in $4 Q$ Levi), this association is neatly expressed in a prayer for purity of the heart.

These major points in the prayer of Levi play an important role in Ammonas' letter, too. In Gr. VII 1 (Syr. XIII 2) Ammonas asserts that the holy spirit was given to the apostles only after they had purified themselves; in Gr. VII 2 (Syr. XIII 2) he continues to argue that even the spirit of repentance is rarely given; it is this spirit that purifies the repentent, before handing them over to the holy spirit; the quotation in Gr. VII 2 (Syr. XIII 3) connects the bestowal of the holy spirit to being a servant of God. Furthermore, as noted above, the Aramaic prayer of Levi was part of the Aramaic Levi Document, which must also have existed in some Greek form. In this document (as in the other sources dealing explicitly with Levi), the prophetic gifts of Levi are emphatically affirmed; Ammonas, too, claims to possess the holy spirit and, on account of that, insight in God's mysteries (Syr. XIII 3, 4).

It is not my contention that the Levi document Ammonas knew is the Aramaic Levi Document in a Greek version. However, Ammonas did know some document in which Levi prominently figured. Moreover, Ammonas' mystical views on the spirit and its associations with moral perfection, purity, and revelatory experiences, seamlessly tie up with the traditional image of Levi, also presented by the Aramaic Levi Document. Given the facts that Ammonas quotes a prayer of Levi, and that the Aramaic Levi Document contained a prayer of Levi; considering, furthermore, that the subject matters of Ammonas' epistle and the Levi documents are closely related, we may conclude that there is a distinct possibility that Ammonas knew the Aramaic Levi Document in some Greek form, although not the Greek form that was probably known to the author of $T$. Levi and/or the copyist responsible for ms. $\varepsilon$.

Of course, other, equally plausible possibilities exist, such as the possibility that Ammonas knew some form of the Testaments, ${ }^{35}$ or some

${ }^{35}$ In a note to Syr. XIV 1, Kmosko suggests that Ammonas knew the Testaments. 
form of Fubilees, or still some other writing containing the same traditional material. Nonetheless, from the sources available to us, it is only the Aramaic Levi Document (and the literary-historically related document in Greek that served as a source for $T$. Levi) that actually contained a prayer of Levi, which concerns, moreover, largely the same subject matter as the quotations of Ammonas and his letter itself. In view of the very general nature of the lines quoted, it is not hard to imagine some form of the prayer of Levi containing these lines.

\section{Conclusion}

My conclusion must remain tentative. It is most likely that Ammonas in his epistle referred to a prayer of Levi, actually existing in writing, although there is no writing extant from which the quotation demonstrably derives. In view of the subject matter of Ammonas' epistle, it is likely that the source quoted presented the traditional image of Levi, known from such writings as Jubilees, the Aramaic Levi Document, and the Testament of Levi, namely the image of a divinely inspired prophet, and a perfect and immaculate saint. Quite possibly, Ammonas had some form of a Greek Levi Document at hand (related to the Aramaic Levi Document, and the source of the Testament of Levi), although it cannot be excluded either that he knew some other text containing a prayer of Levi that was traditio-historically, but not literaryhistorically, related to the Aramaic Levi Document. In any case, these two lines should be added to the corpus of fragments of Levi apocrypha.

\footnotetext{
However, the reference to the patriarchs (not necessarily Jacob's sons only, but quite possibly including Abraham, Isaac, and the other patriarchs) in that passage does not imply a written source: "The patriarchs were very rich in gold and silver, but when approaching death, they did not instruct them (sc. their sons) about anything else but righteousness."
} 